\title{
The potency of alpha-humulene as HER-2 inhibitor by molecular docking
}

\section{Made Harimbawa Putra $\mathbb{D}$, I Putu Ari Anggara Catur Pratama $(\mathbb{D}$, Komang Dian Aditya Putra $\mathbb{D}$, G. A. Desya Pradnyaswari $\left(\mathbb{D}\right.$, Ni Putu Linda Laksmiani* ${ }^{*}$}

Department of Pharmacy, Faculty of Mathematics and Natural Science, Udayana University, Bukit Jimbaran, Badung, Bali 80361, Indonesia

*Corresponding author: Bukit Jimbaran Campus, Udayana University, Badung, Bali 80361, Indonesia. Email: laksmini@unud.ac.id

\begin{abstract}
HER-2 overexpression is present in approximately $20 \%$ of breast cancer. This research aims to study the interactions of a-humulene to HER-2 protein by using in silico molecular docking. The experiment was carried out by HER-2 protein preparation (PDB ID 3PP0), docking validation, a-humulene optimization, and a-humulene docking. The results showed that a-humulene had binding energy of $-7.50 \mathrm{kcal} / \mathrm{mol}$, Van der Waals binding energy of $-7.48 \mathrm{kcal} / \mathrm{mol}$, and electrostatic energy of $-0.02 \mathrm{kcal} / \mathrm{mol}$. a-Humulene is potential as anti-breast cancer towards HER-2 in silico.
\end{abstract}

Keywords: alpha-humulene, anti-breast cancer, HER-2, in silico, molecular docking

\section{Introduction}

Breast cancer is a malignant tumor in the mammary gland tissue originating from the ductal epithelium or its lobules [1]. About $20 \%$ of breast cancer cases are caused by overexpression of HER-2 [2]. The human epidermal growth factor (HER-2) plays a role in proliferation, migration, cell survival and growth [3]. HER-2 overexpression is associated with more aggressive disease, a higher recurrence rate, and shortened survival. In addition, HER-2+ breast cancer has a higher preference for metastasis to the brain [4].

Breast cancer is generally treated by chemotherapy, surgery, radiotherapy, or combination. However, this therapy has several side effects, such as hair loss and drug resistance [5]. Hair loss after chemotherapy is caused by an unspecific drug target [6]. Conventional chemotherapy kills both cancer cells and normal cells. Therefore, it is urgent to develop anticancer drugs that kill cancer cells specifically. One of the drug sources is natural ingredients.

a-Humulene is a monocyclic sesquiterpene that is commonly found in the Zingiberaceae family (Figure 1) [7]. Extracts from Zingiberaceae were tested on MCF-7 breast cancer and HT-29 colon cancer cell lines and produced the small $\mathrm{IC}_{50}$ value from the 11 plants of the Zingiberaceae group [8]. However, no study was found to elucidate $a$-humulene as anti-breast cancer in silico. Molecular docking is a computational simulation to predict the binding between a ligand and a protein, in which ligand is docked to the active site of the receptor [9]. This research aims to study a-humulene activity as anti-breast cancer by inhibiting HER-2 in silico.

\section{Methods \\ Protein preparation}

The HER-2 protein (PDB ID: 3PP0) was downloaded from http://www.rcsb.org/. This target protein was prepared using Chimera 1.11 .1 by separating the protein sequence from $03 \mathrm{Q}$ native ligand.

\section{Validation of docking}

The docking method was validated using the Autodock Tools application (Autodock 4.2 and Autogrid) by redocking (2-\{2-[4-(\{5-chloro-6-[3-(trifluoromethyl) phenoxy] pyridine-3-yl\}amino)-5H-pyrrolo[3,2d] pyrimidin-5-yl] ethoxy\}ethanol) (03Q) native ligand to the prepared HER-2 protein. The grid box was arranged by adjusting the coordinate size of the grid center (X $=16.387 \AA, \mathrm{Y}=17.394 \AA, \mathrm{Z}=26.218 \AA$ ) and grid size $(\mathrm{X}=40 \AA, \mathrm{Y}=40 \AA, \mathrm{Z}=40 \AA)$. The validation parameter of docking protocol was the value of root mean square deviation (RMSD), which is valid if the value of RMSD is less than $\leq 2.0 \AA$.

\section{a-Humulene structure optimization}

The downloaded 3D structure of a-humulene was optimized using HyperChem 8. The optimization 


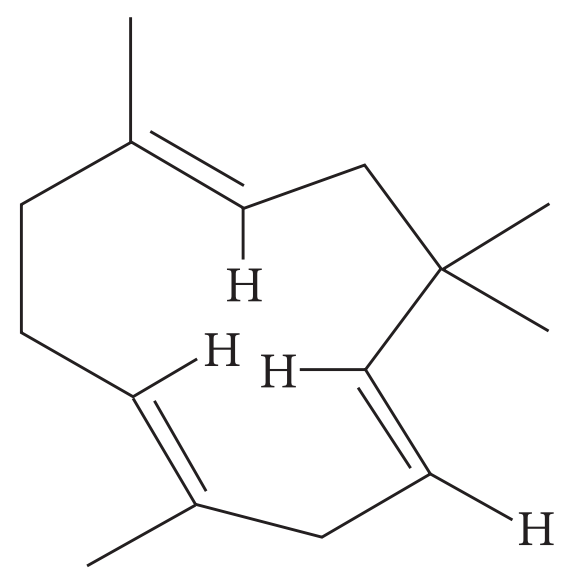

Figure 1. Two dimensional (2D) of a-humulene structure
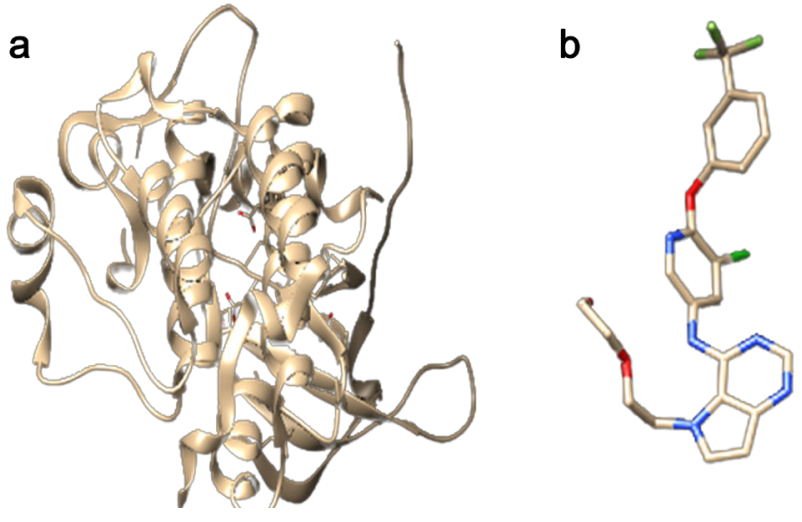

Figure 2. The results of protein preparation. (A) Structure of prepared HER-2 protein target (B) $03 \mathrm{Q}$ native ligand

Table 1. Validation parameters of HER-2 target protein and $03 \mathrm{Q}$ native ligand

\begin{tabular}{|c|c|c|c|c|c|c|}
\hline $\begin{array}{l}\text { Protein } \\
\text { target }\end{array}$ & Ligand & Conformations & RMSD (Å) & $\begin{array}{l}\text { Energy Vdw_Hb_ } \\
\text { desolv (kcal/mol) }\end{array}$ & $\begin{array}{l}\text { Energy elec } \\
\text { (kcal/mol) }\end{array}$ & $\begin{array}{c}\text { Binding } \\
\text { energy (kcal/ } \\
\text { mol) }\end{array}$ \\
\hline \multirow{10}{*}{ HER-2 } & \multirow{10}{*}{$\begin{array}{l}03 Q \text { native } \\
\text { ligand }\end{array}$} & $1^{*}$ & 0.62 & -13.57 & -0.01 & -10.60 \\
\hline & & 2 & 0.71 & -12.74 & -0.02 & -10.50 \\
\hline & & 3 & 0.72 & -13.13 & -0.09 & -10.49 \\
\hline & & 4 & 1.18 & -13.22 & -0.04 & -10.28 \\
\hline & & 5 & 0.69 & -13.43 & -0.04 & -10.24 \\
\hline & & 6 & 2.59 & -11.92 & -0.03 & -9.78 \\
\hline & & 7 & 2.76 & -10.92 & +0.03 & -9.74 \\
\hline & & 8 & 3.53 & -13.49 & +0.01 & -8.97 \\
\hline & & 9 & 2.61 & -11.25 & +0.02 & -8.24 \\
\hline & & 10 & 2.51 & -12.71 & -0.01 & -7.90 \\
\hline
\end{tabular}

step was carried out using the AM1 (Austin Model 1) semi-empirical computational method and single-point calculations and geometry optimization.

\section{Docking a-humulene to the HER-2 protein target}

The optimized $\alpha$-humulene was then docked to the prepared HER-2 target protein using the Autodock 4.2 program. The results gave $\alpha$-humulene conformation with the lowest binding energy to the target protein. The interaction analysis showed the types of bindings such as hydrogen bonds, Van der Waals, hydrophobic, and electrostatics.

\section{Results}

\section{Preparation of HER-2 protein target}

The preparation of HER-2 target protein provided and the protein and $03 \mathrm{Q}$ native ligand (Figure 2).

\section{Docking validation}

The validation parameter of the docking protocol was the RMSD value. The obtained RMSD value was $0.62 \AA$ which is valid $(<2.0 \AA)$. This validation also produced the binding energy between HER-2 target protein and $03 \mathrm{Q}$ native ligand. The binding energy of the selected conformation with the lowest RMSD value was $-13.57 \mathrm{kcal} / \mathrm{mol}$ for Van der Waals, -0.01 $\mathrm{kcal} / \mathrm{mol}$ for electrostatic, and $-10.60 \mathrm{kcal} / \mathrm{mol}$ for free binding energy (Table 1). The visualization indicated the hydrogen bonding occurs between $03 \mathrm{Q}$ native ligand with MET 801 residue (Figure 3).

\section{Optimization of a-humulene}

The 3-dimensional structure (3D) of $\alpha$-humulene was optimized using single-point calculations and geometry optimizations. The single point energy calculation of 


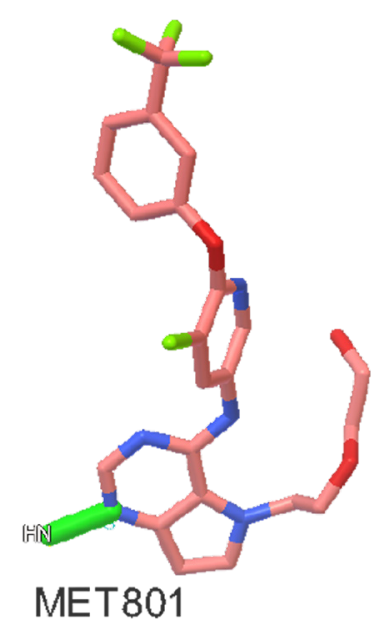

Figure 3. Visualization of $03 \mathrm{Q}$ native ligand with HER-2
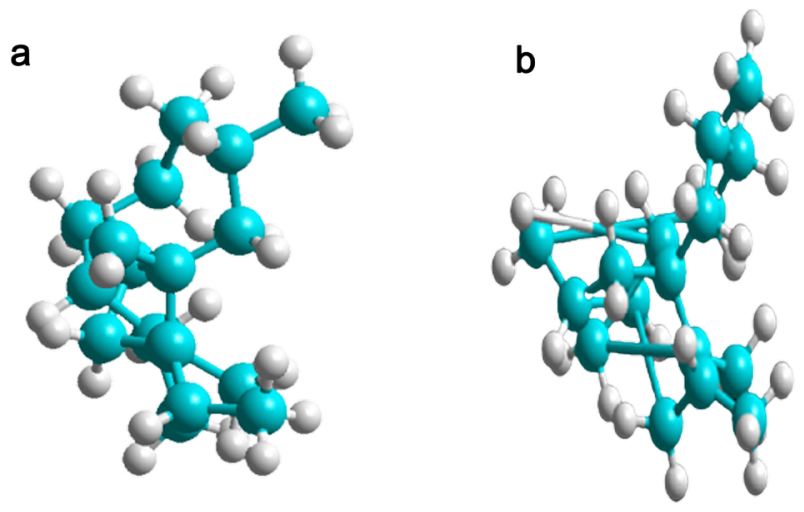

Figure 4. 3D structure $a$-humulene. (A) single point calculation result, and (B) geometry optimization result

Table 2. a-Humulene docking result on HER-2 protein

\begin{tabular}{|c|c|c|c|c|c|}
\hline $\begin{array}{l}\text { Protein } \\
\text { target }\end{array}$ & Ligand & Conformations & $\begin{array}{l}\text { Energy Vdw_Hb_ } \\
\text { desolv (kcal/mol) }\end{array}$ & $\begin{array}{l}\text { Energy elec } \\
\text { (kcal/mol) }\end{array}$ & $\begin{array}{l}\text { Binding energy } \\
\text { (kcal/mol) }\end{array}$ \\
\hline \multirow{10}{*}{ HER-2 } & \multirow{10}{*}{ a-humulene } & $1^{*}$ & -7.48 & -0.02 & -7.50 \\
\hline & & 2 & -6.39 & -0.00 & -6.39 \\
\hline & & 3 & -6.39 & +0.01 & -6.38 \\
\hline & & 4 & -7.31 & -0.02 & -7.33 \\
\hline & & 5 & -6.39 & +0.01 & -6.38 \\
\hline & & 6 & -6.39 & +0.01 & -6.38 \\
\hline & & 7 & -6.39 & -0.00 & -6.39 \\
\hline & & 8 & -6.39 & +0.01 & -6.38 \\
\hline & & 9 & -6.39 & -0.00 & -6.39 \\
\hline & & 10 & -6.39 & -0.00 & -6.39 \\
\hline
\end{tabular}

a-humulene was $-3800.11 \mathrm{kcal} / \mathrm{mol}$, and the energy of geometric optimization was $-4497.19 \mathrm{kcal} / \mathrm{mol}$. The 3D structures of single-point and geometry optimization of a-humulene are displayed in Figure 4.

\section{Docking a-humulene to HER-2 target protein}

The docking process yielded ten bond conformations between a-humulene and HER-2 protein. The most stable conformation of a-humulene with the lowest binding energy had the Van der Waals and hydrophobic energy of $-7.48 \mathrm{kcal} / \mathrm{mol}$, electrostatic energy of $-0.02 \mathrm{kcal} / \mathrm{mol}$, and binding energy of -7.50 $\mathrm{kcal} / \mathrm{mol}$ (Table 2). Visualization analysis showed that a-humulene did not form a hydrogen bonding with HER-2 protein target through MET 801 residue as 03Q native ligand.

\section{Discussion}

The docking protocol was valid, as shown by the RMSD of $0.62 \AA$ ( $\leq 2.0 \AA)$. The docking results showed that the binding energy of $\alpha$-humulene to HER-2 protein was $-7.50 \mathrm{kcal} / \mathrm{mol}$, higher than $03 \mathrm{Q}$ native ligand with $-10.60 \mathrm{kcal} / \mathrm{mol}$. This finding implies that $a$-humulene is potential for HER-2 protein as indicated by the negative value of binding energy.

a-Humulene is one of the sesquiterpenes known for its anti-cancer activity. In silico study of eugenol sesquiterpenes against HER-2 protein obtained the binding energy value of $-4.16 \mathrm{kcal} / \mathrm{mol}$, higher than gefitinib with $-7.05 \mathrm{kcal} / \mathrm{mol}$ as a control [10]. In vitro study indicated that $a$-humulene had a cytotoxic activity with an $\mathrm{IC}_{50}$ of $81.9 \mu \mathrm{g} / \mathrm{mL}$ against the MCF-7 breast cancer cell line [11]. 


\section{Conclusion}

Based on this study, $\alpha$-humulene has the potential as an anti-breast cancer agent by in silico through the inhibition of the HER-2 protein.

\section{Acknowledgment}

None.

\section{Funding}

The authors thank to Direktorat Jenderal Pembelajaran dan Kemahasiswaan Kementerian Riset, Teknologi, dan Pendidikan Tinggi Republik Indonesia funded for this research in the Program Kreativitas Mahasiswa 2021 (grant number 015/E2/PPK/SPPK/PKM/2021).

\section{Declaration of interest}

The authors declare no competing interests.

\section{Author contributions}

IMHP conceptualized the study design; IMHP and IPAACP investigated the data; KDAP and GADP wrote the original draft; IMHP, KDAP and GADP reviewed and edited the final version; IMHP acquitted the funding; NPLL supervised all experiments. All authors read and approved the final manuscript.

Received: 25 September 2021

Accepted: 10 December 2021

Published online: 12 January 2022

\section{References}

1. Waks AG, Winer EP. Breast cancer treatment: A review. JAMA. 2019;321: 288-300. https://doi.org/10.1001/jama.2018.19323

2. Seol H, Lee HJ, Choi Y, Lee HE, Kim YJ, Kim JH, et al. Intratumoral heterogeneity of HER2 gene amplification in breast cancer: its clinicopathological significance. Mod Pathol. 2012;25: 938-948. https://doi.org/10.1038/ modpathol.2012.36
3. Franklin MC, Carey KD, Vajdos FF, Leahy DJ, de Vos AM, Sliwkowski MX. Insights into ErbB signaling from the structure of the ErbB2-pertuzumab complex. Cancer Cell. 2004;5: 317-328. https://doi.org/10.1016/ S1535-6108(04)00083-2

4. Mitri Z, Constantine T, O'Regan R. The HER2 receptor in breast cancer: pathophysiology, clinical use, and new advances in therapy. Chemother Res Pract. 2012;2012: 743193. https://doi.org/10.1155/2012/743193

5. Ogata R, Kishino E, Saitoh W, Koike Y, Kurebayashi J. Resistance to cyclin-dependent kinase (CDK) 4/6 inhibitors confers cross-resistance to other CDK inhibitors but not to chemotherapeutic agents in breast cancer cells. Breast Cancer. 2021;28: 206-215. https://doi.org/10.1007/ s12282-020-01150-8

6. Chon SY, Champion RW, Geddes ER, Rashid RM. Chemotherapy-induced alopecia. J Am Acad Dermatol. 2012;67: e37-47. https://doi.org/10.1016/j.jaad.2011.02.026

7. Sharifi-Rad M, Varoni EM, Salehi B, Sharifi-Rad J, Matthews KR, Ayatollahi SA, et al. Plants of the genus zingiber as a source of bioactive phytochemicals: from tradition to pharmacy. Molecules. 2017;22. https://doi. org/10.3390/molecules22122145

8. Kirana C, Record IR, McIntosh GH, Jones GP. Screening for Antitumor Activity of 11 Species of Indonesian Zingiberaceae Using Human MCF-7 and HT-29 Cancer Cells. Pharm Biol. 2003;41: 271-276. https://doi.org/10.1076/ phbi.41.4.271.15673

9. Meng X-Y, Zhang H-X, Mezei M, Cui M. Molecular docking: a powerful approach for structure-based drug discovery. Curr Comput Aided Drug Des. 2011;7: 146157. https://doi.org/10.2174/157340911795677602

10. Rohmah MK. Studi in silico kompleks ligandreseptoreugenol daun basil (Ocimum basilicum L.) dengan reseptor HER-2 pada non-smallcell lung cancer (NSCLC) dengan kontrol gefitinib. JINTO. 2017;3: 7178. https://doi.org/10.36733/medicamento.v3i2.894

11. Gautam N, Mantha AK, Mittal S. Essential oils and their constituents as anticancer agents: a mechanistic view. Biomed Res Int. 2014;2014: 154106. https://doi. org/10.1155/2014/154106 